\title{
The role of selenium in insulin resistance
}

\author{
Larissa Cristina Fontenelle ${ }^{1}$, Mayara Monte Feitosa ${ }^{1}$, Jennifer Beatriz Silva Morais ${ }^{1}$, \\ Juliana Soares Severo ${ }^{1}$, Taynáh Emannuelle Coelho de Freitas ${ }^{1}$, Jéssica Batista Beserra ${ }^{1}$, \\ Gilberto Simeone Henriques ${ }^{2}$, Dilina do Nascimento Marreiro ${ }^{1 *}$
}

\author{
${ }^{1}$ Department of Nutrition, Federal University of Piauí, Campus Minister Petrônio Portela, Teresina, Piauí, Brazil, \\ ${ }^{2}$ Department of Nutrition, Federal University of Minas Gerais, Belo Horizonte, Minas Gerais, Brazil
}

\begin{abstract}
In recent years, there has been growing interest in clarifying the pathogenesis of some chronic diseases, such as obesity and type 2 diabetes mellitus. Metabolic alterations in these diseases are characterized by chronic hyperglycemia and insulin resistance. Studies have demonstrated the participation of minerals in the pathogenesis of insulin resistance, more specifically their involvement in the synthesis and regulation of insulin. Selenium is an anti-inflammatory and antioxidant micronutrient that is essential for the activity of selenoproteins. Two selenoproteins (glutathione peroxidase and selenoprotein P) are known to be involved in the insulin signaling pathway. The aim of this review is to provide an update on the role of selenium in insulin resistance mechanisms. Evidence shows that adequate concentrations of selenium play a key role in the secretion and action of insulin, but an excess of selenium in the body is associated with the pathogenesis of insulin resistance and the development of diabetes mellitus.
\end{abstract}

Keywords: Diabetes mellitus. Selenium/insulin resistance. Insulin.

\section{INTRODUCTION}

In recent years, the pathogenesis of some chronic diseases has attracted interest, such as obesity and type 2 diabetes mellitus. Metabolic alterations in these diseases are characterized by chronic hyperglycemia and insulin resistance (Rains, Jain, 2011; Steinbrenner, 2013).

Recent studies have attempted to elucidate the molecular alterations involved in the development of insulin resistance. These include reductions in the number and activity of relevant receptors in peripheral tissues, and changes to intracellular insulin signaling pathways (Tencerova et al., 2015; Winnier et al., 2015). Accordingly, minerals have been the subject of several studies, focusing specifically on their involvement in the synthesis and regulation of insulin (Cruz et al., 2014; Garcia et al., 2013).

Selenium is an anti-inflammatory and antioxidant micronutrient essential for the activity of selenoproteins, such as glutathione peroxidase (GPx) and selenoprotein $\mathrm{P}$ (Sepp). These enzymes are also involved in insulin

\footnotetext{
*Correspondence: D. N. Marreiro. Departamento de Nutrição, Universidade Federal do Piauí, Campus Ministro Petrônio Portela, Bairro Ininga, 64049550 Teresina, Piauí, Brasil. Telephone: +55 (86) 999915019 / +55 (86) 988459778/ Fax:+55 (86) 32371812. E-mail: dilina.marreiro@gmail.com
}

regulation (Cominetti et al., 2011; Steinbrenner et al., 2013; Wei et al., 2014; Zou et al., 2016). Several studies have revealed selenium to be an insulin-mimetic, because it plays roles in the regulation of enzymes in the insulin signaling cascade, the expression of lipogenic enzymes, and in carbohydrate metabolism in the liver (Chen et al., 2015; Iizuka et al., 2010; Mao, Teng, 2013).

However, it has been emphasized that chronic ingestion of large amounts of selenium promotes the formation of antioxidant selenoproteins, leading to reduced concentrations of reactive oxygen species, which are required in physiological amounts for insulin signaling (Labunskyy et al., 2011; Wang et al., 2014; Zhou et al., 2015).

Given that insulin resistance is a key metabolic disorder that can result in the development of chronic diseases such as type 2 diabetes mellitus, and that selenium participates in the prevention of this disease, we have reviewed the participation of this micronutrient in insulin resistance.

\section{Etiologic factors of insulin resistance}

Insulin has a crucial function in glucose homeostasis; it regulates the balance between glucose production by the 
liver, and glucose uptake by muscle and adipose tissue. In myocytes and adipocytes, insulin regulates glucose transport by controlling the translocation of a glucose transporter (GLUT4) to the plasma membrane (Bruce, Hanson, 2010; Kim, Feldman, 2015).

The insulin receptor is a tetramer composed of two extracellular $\alpha$-subunits and two transmembrane $\beta$-subunits. The action of insulin is initiated through binding to the $\alpha$-subunits, which alters the conformation of the $\beta$-subunits. This results in autophosphorylation and activation of its tyrosine kinase function. The $\beta$-subunit can autophosphorylate, and it can phosphorylate other proteins or intracellular substrates, such as insulin receptor substrate 1 (IRS-1), insulin receptor substrate 2 (IRS-2), and the Src homology collagen (Shc) family of proteins (Hirabara et al., 2014; Litvinova et al., 2014).

The action of insulin is mediated by three main signaling cascades: the phosphatidyl inositol 3-kinase (PI3K)/protein kinase B (Akt) pathway, the Cbl associated protein (CAP)/Cbl pathway, and the Ras/mitogen-activated protein kinase (MAPK) pathway. These pathways regulate relevant cellular processes, such as glucose uptake, protein synthesis, and the expression of genes involved in cellular proliferation and differentiation (Litvinova et al., 2014).

Phosphorylation of IRS-1 (a process performed by various protein kinases, particularly $\mathrm{PI} 3 \mathrm{~K}$ ) results in the formation of binding sites for proteins containing the Src homology 2 domain ( $\mathrm{SH} 2$ ). This activation is required for stimulation of glucose transport by insulin, and is sufficient to induce GLUT4 translocation to the plasma membrane, at least partially. After phosphorylation by PI3K, IRS1 begins to activate other cytoplasmic substrates, such as serine kinases, protein kinase B (Akt), and atypical isoforms of protein kinase $\mathrm{C}(\mathrm{aPKC} \zeta$ and $\mathrm{aPKC} / \lambda)$. Once phosphorylated, these proteins participate in insulin signal transduction pathways for glucose transport (Kwon, Pessin, 2013).

In addition to PI3K activation, other signals are required for insulin-stimulated glucose transport. In the second pathway, activation of the insulin receptor leads to phosphorylation of the $\mathrm{Cbl}$ oncogene. In most insulinsensitive tissues, $\mathrm{Cbl}$ is associated with the adapter protein CAP. After phosphorylation, the Cbl-CAP complex migrates to the cell membrane and interacts with the CrkII protein, which in turn is associated with the $\mathrm{C} 3 \mathrm{G}$ protein. $\mathrm{C} 3 \mathrm{G}$ is a nucleotide exchanger that catalyzes the conversion of GDP to GTP in the TC10 protein, thus activating it. Once activated, TC10 generates a second signal for translocation of the GLUT4 protein, in parallel with the activation of PI3K (Hirabara et al., 2012; Litvinova et al., 2014).
In a similar manner to other growth factors, insulin stimulates MAPK. This pathway begins with the phosphorylation of IRS and/or Shc proteins, which interact with growth factor receptor binding protein 2 (Grb2). The latter is constitutively associated with Son of Sevenless (SOS), which is a protein that exchanges GDP for GTP in Ras (a GTP-binding switch protein), thus activating it. Activation of Ras requires the participation of Src homology phosphatase 2 (SHP2). Once activated, Ras stimulates serine phosphorylation of the MAPK cascade, which promotes cellular proliferation and/or differentiation. Pharmacological blockade of this pathway prevents the effect of insulin on cell growth, but has no effect on insulin's metabolic properties (Hirabara et al., 2012).

The term insulin resistance refers to the reduced sensitivity of peripheral tissues to the action of insulin, which is caused by changes in insulin-mediated signaling pathways, and results in systemic hyperglycemia. Causes of insulin resistance include various metabolic aberrations that reduce the capacity of tissues to respond to insulin, especially in the liver, adipose tissue, and muscle (Tencerova et al., 2015; Winnier et al., 2015).

At various stages of insulin resistance, some tissues, such as skeletal muscle and adipose tissues, regulate GLUT4 expression differently. In the adipocytes of obese individuals, the concentration of GLUT4 is reduced, while concentrations in the skeletal muscle are normal. Since skeletal muscle is the main site for insulin-stimulated glucose consumption, changes in systemic sensitivity to insulin in obese and diabetic individuals cannot be explained by the reduced production of GLUT4. Instead, insulin resistance in these patients is explained by the low glucose uptake in skeletal muscle, which is due to the reduced translocation of GLUT4 from intracellular vesicles to the cell membrane (Muntoni, Muntoni, 2011; Slattery et al., 2014).

It is important to note that regulation of the cellular redox balance is necessary to maintain and adapt insulin secretion, and to promote sensitivity of the target tissues to insulin. In this sense, oxidative stress is related to the multifactorial etiology of insulin resistance, with effects mainly observed in skeletal muscle tissues (Steinbrenner, 2013; Henriksen, Diamond-Stanic, Marchionne, 2011).

Several systemic and cellular problems may contribute to increased production of reactive oxygen species, such as hyperglycemia, dyslipidemia, endoplasmic reticulum stress, advanced glycation end products, and lipid peroxides. These conditions can activate factors that are associated with reduced insulin action. These factors include the impairment of insulin signaling by phosphorylation of IRS on serine and threonine residues, alteration of cellular redistribution 
of insulin signaling components, decreased transcription of the GLUT4 gene, and changes in mitochondrial activity (Henriksen, Diamond-Stanic, Marchionne, 2011; Rains, Jain, 2011; Steinbrenner, 2013).

In this regard, two mechanisms of reactive oxygen species production appear to be most relevant to the etiology of insulin resistance: the excess mitochondrial production of hydrogen peroxide $\left(\mathrm{H}_{2} \mathrm{O}_{2}\right)$, and the increased activation of NADPH oxidase. Excess $\mathrm{H}_{2} \mathrm{O}_{2}$ production promotes mitochondrial dysfunction, which can affect insulin secretion in pancreatic $\beta$-cells. Excess $\mathrm{H}_{2} \mathrm{O}_{2}$ production is also involved in insulin resistance in skeletal muscle, particularly among individuals with high-energy expenditure, such as increased lipid intake. The increase in NADPH oxidase activation is mediated by angiotensin II receptors, which generate superoxide anions and impair insulin signaling by disrupting the translocation of GLUT4 (Henriksen, Diamond-Stanic, Marchionne, 2011; Rains, Jain, 2011).

\section{Selenium and insulin resistance}

Changes in selenium status appear to contribute significantly to the development of insulin resistance (Feng et al., 2015; Kim, Song, 2014; Pounis et al., 2014). Previous research has shown that dietary supplementation with selenium can reduce fasting serum insulin concentrations and the insulin resistance index (Alizadeh et al., 2012; Bahmani et al., 2016; Farrokhian et al., 2016). The main findings of studies that have investigated the role of selenium on insulin resistance are described in Tables I and II.

TABLE I - Selenium, glycemic parameters and insulin resistance: a summary of human studies

\begin{tabular}{|c|c|c|c|}
\hline Study Design & Selenium Levels & Results & Ref. \\
\hline \multicolumn{4}{|c|}{ Prospective cohort study } \\
\hline $\begin{array}{l}\text { Men and women from Sweden }(\mathrm{n}= \\
1925) \text {, aged }>50 \text { years, follow-up } \\
\text { of } 20 \text { years }\end{array}$ & $\begin{array}{c}\text { Serum selenium } \\
\text { Baseline: } 75.6 \pm 14.3 \mu \mathrm{g} / \mathrm{L} \text { (range } \\
\text { of } 24-132.8 \mu \mathrm{g} / \mathrm{L} \text { ) }\end{array}$ & $\begin{array}{l}\text { No significant associations found between serum } \\
\text { selenium levels at baseline and glucometabolic } \\
\text { traits (fasting blood glucose, fasting serum } \\
\text { insulin, proinsulin, intravenous glucose tolerance } \\
\text { test, HOMA-IR }{ }^{b} \text {, HOMA-B } \text {, and type } 2 \text { diabetes } \\
\text { risk). }\end{array}$ & $\begin{array}{c}\text { Gao et al., } \\
2014\end{array}$ \\
\hline
\end{tabular}

\section{Cross-sectional studies}

\begin{tabular}{lcc}
\hline & Higher fasting plasma glucose levels: quartiles 3 \\
arinary selenium & and 4 vs. the lowest of urinary selenium. \\
Men and women from China $(\mathrm{n}=$ & Quartile 1: $<4.55$ & OR $^{\mathrm{d}}$ for diabetes compared to quartile 1: quartile \\
$2242)$, aged $=53.0 \pm 13.2$ years & Quartile 3: $7.50-11.76$ & $1.968)]$ and quartile $4[1.574(0.968,2.559)]$. \\
& Quartile 4: $>11.76$ & No significant associations with impaired fasting \\
& & glucose risk. \\
\hline
\end{tabular}

Men and women in Korea, aged 19-85 years

- Group A: $\mathrm{n}=71$ visceral obese

- Group B: $\mathrm{n}=73$ controls

Men with visceral obesity $(\mathrm{n}=78)$

from Indonesian, median age $=37$

years

Hair selenium Group A: $0.053 \pm 0.003 \mathrm{mg} \%$ Group B: $0.055 \pm 0.003 \mathrm{mg} \%$
No differences in hair selenium concentrations between groups.

Hair selenium negatively correlated with HOMA- Kim, Song, 2014 $\operatorname{IR}^{\mathrm{b}}(\mathrm{r}=-0.251)$ and insulin $(\mathrm{r}=-0.306)$ only in the viscerally obese group.

$$
\begin{aligned}
& \text { Plasma selenium } \\
& \text { approaching or above } \\
& 70 \mathrm{ng} / \mathrm{mL}
\end{aligned}
$$

\begin{tabular}{|c|c|c|c|}
\hline \multirow{7}{*}{$\begin{array}{l}\text { Women without diabetes from } \\
\text { Italy }(n=6879 \text { men and } 6891 \\
\text { women }) \text {, aged }=53.1 \pm 11.0 \text { years })\end{array}$} & \multirow{6}{*}{$\begin{array}{c}\text { Selenium intake } \\
\text { Quartile 1: }<50 \mu \mathrm{g} / \text { day } \\
\text { Quartile 2: 50-60 } \mathrm{g} / \text { day } \\
\text { Quartile 3: 61-75 } \mu \mathrm{g} / \text { day } \\
\text { Quartile 4: }>75 \mu \mathrm{g} / \text { day }\end{array}$} & Dietary selenium was positively associated with & \multirow{7}{*}{$\begin{array}{c}\text { Pounis et al., } \\
2014\end{array}$} \\
\hline & & \multirow{6}{*}{$\begin{array}{c}\text { blood glucose }(\mathrm{p}<0.05) \text {. } \\
\text { Increase of } 50 \mu \mathrm{g} / \text { day in dietary selenium was } \\
\text { associated with increases of } 0.14 \text { (men) and } 0.11 \\
\mathrm{mmol} / \mathrm{L} \text { (women) in fasting blood glucose levels. } \\
\mathrm{OR}^{\mathrm{d}} \text { for diabetes (highest vs. lowest quartiles): } \\
1.33(1.01,1.77) \text { for men and } 1.71(1.17,2.51) \\
\text { for women. }\end{array}$} & \\
\hline & & & \\
\hline & & & \\
\hline & & & \\
\hline & & & \\
\hline & & & \\
\hline
\end{tabular}

$\begin{array}{cc}\text { No significant correlation between selenium } & \\ \text { concentrations and glucose homeostatic } & \text { Mutakin } \text { et al., } \\ \text { parameters (fasting glucose plasma and HOMA- } & 2013\end{array}$
$\left.I^{b}\right)$. 
TABLE I - Selenium, glycemic parameters and insulin resistance: a summary of human studies (cont.)

\begin{tabular}{|c|c|c|c|}
\hline Study Design & Selenium Levels & Results & Ref. \\
\hline \multicolumn{4}{|c|}{ Randomized double-blind placebo-controlled clinical trials } \\
\hline $\begin{array}{l}\text { Premenopausal women with } \\
\text { central obesity from Iran }(\mathrm{n}=84) \text {, } \\
\text { aged } 20-50 \text { years } \\
\text { - Group A }(\mathrm{n}=17) \text { : HDEL }{ }^{\mathrm{a}}+ \\
\text { placebo } \\
\text { - Group B }(\mathrm{n}=17): \mathrm{HDEL}^{\mathrm{a}}+ \\
\text { arginine }(5 \mathrm{~g} / \text { day) } \\
\text { - Group C }(\mathrm{n}=17): \mathrm{HDEL}^{\mathrm{a}}+ \\
\text { selenium }\left(200 \mu \mathrm{g} / \text { day }^{-}\right. \\
\text {- Group D }(\mathrm{n}=17): \mathrm{HDEL}^{\mathrm{a}}+ \\
\text { arginine + selenium } \\
\text { - 8-week intervention }\end{array}$ & Not evaluated. & $\begin{array}{l}\text { Selenium supplementation significantly lowered } \\
\text { fasting concentrations of serum insulin and } \\
\text { HOMA-IR }{ }^{\mathrm{b}} \text { in group C. }\end{array}$ & $\begin{array}{l}\text { Alizadeh et al., } \\
2012\end{array}$ \\
\hline
\end{tabular}

Men and women from France, aged

35-60 years

- Group A ( $=1533)$ : antioxidant

Selenium plasma supplement [120 mg vitamin $\mathrm{C}$,

Baseline:

$30 \mathrm{mg}$ vitamin E, $6 \mathrm{mg} \beta$-carotene, Group A: $1.10 \pm 0.19$ (women) and $100 \mu \mathrm{g}$ Se (in the form of selenium- $1.15 \pm 0.21$ (men) mmol/LGroup enriched

B: $1.09 \pm 0.20$ (women) and $1.13 \pm$ yeast) and $20 \mathrm{mg} \mathrm{Zn)]}$

0.19 (men) $\mathrm{mmol} / \mathrm{L}$

No significant difference in age-adjusted mean fasting plasma glucose between groups. Baseline plasma concentrations of selenium were positively $(\mathrm{p}<0.0001)$ associated with fasting

Czernichow et al., 2006 plasma glucose.

- Group B ( $=1613)$ : placebo

- intervention for $7.5 \pm 0.3$ years

Patients with type 2 diabetes mellitus from Iran, aged 18-70 years

- Group A ( $=33): 200 \mu$ g daily selenium supplements (selenium yeast)

- Group B (n=27): placebo Serum selenium Baseline: $42.69 \mu \mathrm{g} / \mathrm{L}$ (group A) and $47.11 \mu \mathrm{g} / \mathrm{L}$ (group B).

After supplementation: $71.98 \mu \mathrm{g} / \mathrm{L}$ (group A) and $45.38 \mu \mathrm{g} / \mathrm{L}$ (group

B).

- 12-week intervention

Patients with type 2 diabetes mellitus and stable coronary heart disease from Iran, aged 45-85 years

- Group A ( $=27): 200 \mu$ g daily

selenium supplements

- Group B ( $=27)$ : placebo - 8-week intervention
Selenium intake: no significant differences between groups before and after supplementation.
An increase in fasting plasma glucose $(\mathrm{p}<0.01)$ as compared with the placebo.
Faghihi et al., 2014

aHDEL: hypocaloric diet enriched in legumes; ${ }^{b} \mathrm{HOMA}-\mathrm{IR}$ : homeostasis model assessment of insulin resistance; ${ }^{\mathrm{c} H O M A-B:}$ homeostasis model assessment of $\beta$-cell function; ${ }^{\mathrm{d} O R}$ : odds ratio; ${ }^{\mathrm{e}} \mathrm{QUICKI}$ : quantitative insulin sensitivity check index. 
TABLE II - Selenium, glycemic parameters and insulin resistance: a summary of studies in cellular and non-human animal models

\begin{tabular}{|c|c|c|c|}
\hline Study Model & Selenium Treatment & Main Results & Ref. \\
\hline \multicolumn{4}{|c|}{ Non-human animal studies } \\
\hline $\begin{array}{l}\text { Diabetic rats (Sprague- } \\
\text { Dawley) }\end{array}$ & $\begin{array}{c}\text { Sodium selenite }(5 \mathrm{ppm}) \\
\text { at a drinking water for } 4 \\
\text { weeks }\end{array}$ & $\begin{array}{l}\text { - } \downarrow \text { blood glucose; } \\
\text { - Restored the plasma level of GLP-1 to its normal range; } \\
\text { - } \uparrow \text { GLP-1R mRNA level and restored the GLP-1R } \\
\text { protein level in the liver to its normal level; } \\
-\downarrow \text { mRNA levels of IRS- } 1 \text { and restored IRS-1 protein } \\
\text { level in the liver to its normal level; } \\
\text { - Reduced the increase in both the Raf- } 1^{\text {a }} \text { mRNA and } \\
\text { protein levels in the liver. }\end{array}$ & $\begin{array}{c}\text { Barakat, Moustafa, } \\
\text { Bikhazi, } 2012\end{array}$ \\
\hline $\begin{array}{l}\text { Diabetic rats (Sprague- } \\
\text { Dawley) }\end{array}$ & $\begin{array}{c}\text { Sodium selenite ( } 5 \mathrm{ppm}) \\
\text { at a drinking water for } 4 \\
\text { weeks }\end{array}$ & $\begin{array}{l}\text { - } \uparrow \text { GLP-1R and IRS- } 1 \text { mRNA levels with no significant } \\
\text { change in protein levels in the pancreas; } \\
\text { - } \uparrow \text { preproinsulin mRNA levels in the pancreas; } \\
\text { - } \uparrow \text { number of endocrine islet in the pancreatic tissue } \\
\text { with restoration of normal cellularity and viable cells. }\end{array}$ & Barakat et al., 2016 \\
\hline
\end{tabular}

\begin{tabular}{|c|c|c|c|}
\hline $\begin{array}{l}\text { Diabetic rats (Goto- } \\
\text { Kakizaki) }\end{array}$ & $\begin{array}{l}\text { 1) Daily intraperitoneal } \\
\text { injections of sodium } \\
\text { selenate }(0.173 \mathrm{mg} / \mathrm{kg} \\
\text { body weight) for } 14 \text { days; } \\
\text { 2) Samples of isolated } \\
\text { adipocytes incubated } \\
\text { with } 50 \mu \mathrm{L} \text { solutions of } \\
\text { various concentrations } \\
\text { of sodium selenate } \\
\text { (final concentration } 1 \\
\mu \mathrm{mol} / \mathrm{L}-10 \text { mmol/L). }\end{array}$ & $\begin{array}{l}\text { - The glucose uptake and the suppression of hepatic } \\
\text { glucose output were similar between control rats and } \\
\text { sodium selenate-treated GK rats; } \\
\text { - } \uparrow \text { basal 2-deoxyglucose uptake in the presence of } \\
\text { insulin into adipocytes; } \\
\text { - Glucose incorporation was potentiated by sodium } \\
\text { selenate into adipocytes. }\end{array}$ & Iukuza et al., 2010 \\
\hline $\begin{array}{l}\text { 1) Rats } \\
\text { 2) Hepatocyte cell line } \\
\text { BRL-3A }\end{array}$ & $\begin{array}{c}\text { 1) Intragastric } \\
\text { administration: } 219 \mu \mathrm{g} / \\
\mathrm{kg}(\text { Group 1) or } 438 \mu \mathrm{g} / \\
\mathrm{kg} \text { (Group 2) of sodium } \\
\text { selenite daily for } 6 \text { weeks. } \\
\text { 2) Incubation with } \\
\text { sodium selenite }(1 \mu \mathrm{M} \text { or } \\
10 \mu \mathrm{M}) \text { for } 36 \text { hours }\end{array}$ & $\begin{array}{l}-\uparrow \text { blood glucose levels (Group } 2) \text {; } \\
\text { - Impaired glucose and insulin tolerance (Group } 2) \text {; } \\
\text { - } \downarrow \text { insulin-stimulated phosphorylation of Akt both in } \\
\text { rats (Group } 2 \text { ) and in hepatocytes ( } 10 \mu \mathrm{M}) \text {; } \\
\text { - } \uparrow \text { expression of phosphoenolpyruvate carboxykinase } \\
\text { and glucose-6-phosphate both in rats (Group } 2 \text { ) and in } \\
\text { hepatocytes ( } 10 \mu \mathrm{M}) \text {; } \\
\text { - } \downarrow \text { insulin-stimulated glycogen synthesis in hepatocytes } \\
(10 \mu \mathrm{M}) \text {. } \\
\text { - } \uparrow \text { free fatty acids content in the liver (Group } 2) \text { and in } \\
\text { hepatocytes }(10 \mu \mathrm{M}) \text {; } \\
\text { - } \uparrow \text { mitochondrial reactive oxygen species production in } \\
\text { the liver (Group } 2) \text { and in hepatocytes }(10 \mu \mathrm{M}) \text {. }\end{array}$ & Wang et al., 2014 \\
\hline
\end{tabular}


TABLE II - Selenium, glycemic parameters and insulin resistance: a summary of studies in cellular and non-human animal models (cont.)

\begin{tabular}{|c|c|c|c|}
\hline Study Model & Selenium Treatment & Main Results & Ref. \\
\hline $\begin{array}{l}\text { Female Wistar rats and its } \\
\text { offspring* }\end{array}$ & $\begin{array}{c}\text { Se-enriched yeast for } 5 \\
\text { weeks } \\
\text { Group } 1 \text { (deficient): } \\
\text { basal diet }(12 \mu \mathrm{g} / \mathrm{kg} \text { of } \\
\text { selenium) } \\
\text { Group } 2 \text { (adequate): } \\
\text { basal diet }+0.3 \mathrm{mg} / \mathrm{kg} \text { of } \\
\text { selenium } \\
\text { Group } 3 \text { (high): basal diet } \\
+3.0 \mathrm{mg} / \mathrm{kg} \text { of selenium } \\
\text { *The pups were fed } \\
\text { the same diet as their } \\
\text { respective dam. }\end{array}$ & $\begin{array}{l}\text { - } \uparrow \text { insulin and glucose levels on day } 19 \text { of gestation and } \\
\text { day } 14 \text { postpartum, respectively (Group 3); } \\
\text { - Glucose tolerance and insulin resistance impaired on } \\
\text { day } 19 \text { of gestation (Grupo 3); } \\
\text { - Offspring were glucose intolerant and insulin resistant } \\
\text { (Grupo 3); } \\
\text { - } \downarrow \text { mRNA levels of Akt2, Insrc , Irs } 1 \text { and FoxO1 in liver } \\
\text { of the offspring (Grupo 3); } \\
\text { - } \downarrow \text { mRNA levels of Irs } 2 \text { and Pgc-1 in muscle of the } \\
\text { offspring (Grupo 3). }\end{array}$ & Zeng et al., 2012 \\
\hline Diabetic rats (Wistar) & $\begin{array}{l}\text { Sodium selenite }(1 \mathrm{ppm}) \\
\text { at a } \\
\text { drinking water for } 2 \text { or } 4 \\
\text { weeks }\end{array}$ & $\begin{array}{l}\text { - } \downarrow \text { serum glucose after } 2 \text { and } 4 \text { weeks; } \\
\text { - } \uparrow \text { insulin levels after } 2 \text { and } 4 \text { weeks; } \\
\text { - Improved hepatic antioxidant status after } 4 \text { weeks; } \\
\text { - Overall improvement in histoarchitecture of the liver, } \\
\text { with reduction of lipid deposition and lymphocytic } \\
\text { infiltration. }\end{array}$ & Zou et al., 2016 \\
\hline
\end{tabular}

\section{Cell studies (in vitro)}

- Significant 5-fold increase in GPx activity;

1) Incubation with sodium selenite

1) Mouse beta-cell line Min6

2) Isolated rat islets of Langerhans

\section{(30 nmol/L) for 3 hours.}

2) Incubation with sodium selenite

( $30 \mathrm{nmol} / \mathrm{L})$ for 72 hours.
- 3.5-fold increase in the activity of the Ipf $1^{\text {d }}$ promoter and a 7-fold increase in the activity of the beta-cell specific section of this promoter;

- $\uparrow$ Ipfl mRNA and protein levels;

Campbell et al., 2008

- $\uparrow$ insulin mRNA levels;

- $\uparrow$ insulin content and secretion from isolated rat islets of Langerhans;

- $\downarrow$ intracellular reactive oxygen species generation with

Incubation with $1 \mu \mathrm{M}$ to $100 \mu \mathrm{M}$ of various selenium compounds

L6C11 rat skeletal muscle cell line selenite $(1 \mu \mathrm{M})$ exhibiting the most pronounced effect followed by selenomethionine $(10 \mu \mathrm{M})$;

- $\downarrow$ insulin-induced phosphorylation of Akt by selenite and methylseleninic acid $(1 \mu \mathrm{M})$;

Pinto et al., 2011

sodium selenite, methylseleninic acid or sodium selenate) for 24 hours.

- $\downarrow$ insulin-stimulated glucose uptake by selenite $(5 \mu \mathrm{M})$ and methylseleninic acid $(1 \mu \mathrm{M})$;

- $\uparrow$ insulin-stimulated glucose uptake by selenomethionine $(100 \mu \mathrm{M})$.

${ }^{\mathrm{a}}$ Raf1: Raf-1 proto-oncogene, serine/threonine kinase; ${ }^{\mathrm{b}} \mathrm{HbA1C}$ : Glycated hemoglobin A1C; ${ }^{\mathrm{I}}$ Insr: insulin receptor; ${ }^{\mathrm{d}} \mathrm{Ipf1}$ : insulin promoter factor 1.

Selenium's antidiabetic action appears to result from its behaviour as an insulin-mimetic and as an antioxidant nutrient, since insulin signaling, and secretion is associated with the cellular redox state (Mao, Teng, 2013; Rayman, Stranges, 2013; Steinbrenner, 2013). In a study performed by Barakat, Moustafa and Bikhazi (2012), it was found that 4 weeks of treatment with sodium selenite $(5 \mathrm{ppm}$ in drinking water) increased mRNA and protein levels of glucagon-like peptide-1 receptor (GLP-1R) in the liver of diabetic rats, which may have favored the reduction of blood glucose levels. It is worth mentioning that GLP-1 appears to reduce hepatic glucose production by promoting glycogen synthesis (D'Alessio, Vahl, Prigeon, 2004).

In a subsequent study using the same experimental model, these researchers investigated the effects of selenium treatment in the pancreas of diabetic rats. Increases in GLP-1R, IRS-1 and preproinsulin mRNA levels were found. Moreover, selenium treatment improved the number of endocrine islets, with restoration of normal cellularity and viable cells in the pancreatic 
tissue (Barakat et al., 2016). The effects of GLP-1 on the biosynthesis and secretion of insulin, as well as the proliferation, differentiation and apoptosis of pancreatic $\beta$ cells, are well known (Lee, Jun, 2014). In this regard, these results suggest a possible role of selenium in the physiological actions of incretin hormones.

Similarly, Campbell et al. (2008) found that selenium participates in insulin's action on $\beta$-pancreatic cells, through its ability to regulate the gene expression of insulin promoter factor 1 , and to increase the mRNA expression of insulin in the mouse beta cell line Min6. Selenium promotes the increased production and secretion of insulin in these cells.

In a study by Iukuza et al. (2010), $0.173 \mathrm{mg} /$ $\mathrm{kg}$ of sodium selenite $\left(\mathrm{Na}_{2} \mathrm{SeO}_{3}\right)$ was administered intraperitoneally to diabetic rats for 14 days. The result was increased glucose uptake by peripheral tissues and adipocytes. This was probably due to the action of selenium on the insulin receptor, thus increasing sensitivity to insulin and alleviating hyperglycemia, for regulation of hepatic glucose production.

It is important to mention selenium's role in the regulation of the hepatic metabolism of carbohydrates. Chen et al. (2015) found that the administration of selenium to diabetic rats (through a $1 \mathrm{ppm}$ dose in their drinking water) increased cellular glucose uptake and restored the activity of glucose-6-phosphatase and glycogen phosphorylase (enzymes involved in the hepatic glucose production) to normal levels.

Pancreatic $\beta$-cells are known for their reduced antioxidant protection, probably due to the important role played by physiological concentrations of reactive oxygen species in insulin signaling pathways. Research has revealed lower expression of GPx selenoproteins, and higher expression of Sepp 1 in these cells. These findings are suggestive of a possible role of selenium in the regulation of the redox state of pancreatic $\beta$-cells (Lei, Vatamaniuk, 2011; Steinbrenner et al., 2013).

A study by Steinbrenner et al. (2013) showed that Sepp1 can provide additional antioxidant protection to the islets of Langerhans, serving as a selenium donor for the function of other antioxidant selenoproteins such as Gpx, and participating in the protection of cell membranes from oxidative damage. Sepp 1 is also located in glucagon-secreting cells. Nevertheless, elevated glucose concentrations (11-22 mM) appear to dysregulate the expression of Sepp 1 in $\beta$-cells, which can reduce antioxidant function and trigger endocrine dysfunction.

Labunskyy et al. (2011) found that a deficiency of Sepp 1 and methionine sulfoxide reductase 1 (MsrB1) in transgenic mice induces glucose intolerance and hyperinsulinemia. Research by Zou et al. (2016) showed that selenium treatment (a 1 ppm dose in drinking water) in diabetic rats reduces serum glucose concentration, lipid peroxidation, and the activity of the enzymes aspartate aminotransferase, alanine aminotransferase, and alkaline phosphatase. The authors also demonstrated that selenium supplementation increased the activity of major antioxidant enzymes, such as GPx, superoxide dismutase, and catalase. Figure 1 shows the participation of selenium in protection from insulin resistance.

On the other hand, selenium may also impair insulin's action in target cells. Some studies have shown an association of high dietary selenium intake with increased risk of diabetes and insulin resistance (Table I and II) (Pounis et al., 2014; Stranges et al., 2007). The negative action of selenium on insulin signaling pathways appears to relate to dysregulation of the cellular redox state (Labunskyy et al., 2011; Wang et al., 2014).

In this context, the overexpression of antioxidant selenium-dependent enzymes promotes the removal of intracellular hydrogen peroxide, which is a reactive oxygen species that regulates key enzymes for insulin signaling. In turn, this promotes the dephosphorylation of the enzymes of insulin signaling, thereby inactivating them and changing the action of insulin (Steinbrenner, 2013; Wang et al., 2014; Zhou, Huang, Lei, 2013). In particular, some investigators have described the inhibition of phosphorylation of specific enzymes of the insulin signaling pathway, such as Akt and 5'-adenosine monophosphate-activated protein kinase (AMPK), caused by the elevated expression of GPx or Sepp 1. Sepp1 also inhibits phosphorylation of the tyrosine residue on hepatocyte insulin receptors, and promotes the phosphorylation of a serine residue in IRS-1 (Misu et al., 2010; Steinbrenner, 2013; Wang et al., 2014).

Zeng et al. (2012) found that in rats, a diet rich in selenium (3.0 mg/kg per day) can induce hyperinsulinemia, insulin resistance, and glucose intolerance. High selenium intake also reduces the mRNA expression or protein levels of six factors that participate in insulin signaling pathways in the liver and muscle, and increases the activity of GPx 1 in the pancreas, liver, and erythrocytes.

Similarly, Labunskyy et al. (2011) found that under conditions of high selenium intake (a $0.4 \mathrm{ppm}$ dose of sodium selenite), there is increased expression of the antioxidant selenoproteins GPx1 and MsrB1, and a positive correlation between GPx1 overexpression and the expression of other selenoproteins, such as SelS and SelT. These findings suggest that the factors described may participate in the impairment of insulin signaling. The authors suggest that the cellular dysregulation of the 


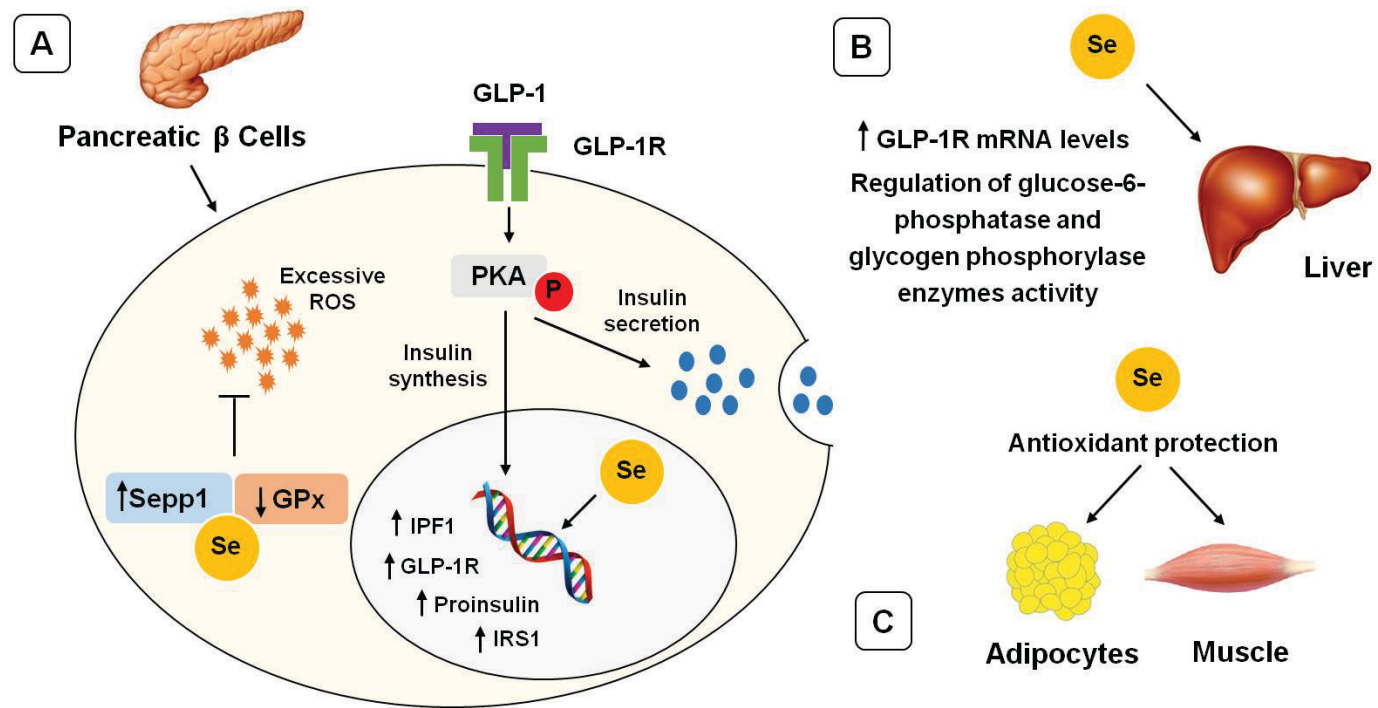

FIGURE 1 - The role of selenium in protection from insulin resistance. Overall, selenium appears to improve insulin resistance through three mechanisms. A) Firstly, in $\beta$-pancreatic cells, selenoproteins such as Sepp1 and Gpx exert antioxidant action, thereby inhibiting the excessive production of reactive oxygen species, which may impair the insulin signaling pathway. Moreover, selenium promotes the transcription and synthesis of proinsulin, insulin promoter factor 1, and GLP-1R. In the figure, we highlight the participation of the GLP-1-activated protein kinase A pathway in the regulation of insulin secretion and synthesis. B) Secondly, in the liver, selenium influences hepatic glucose production, by regulating glucose-6-phosphatase and glycogen phosphorylase enzymatic activity, and increasing GLP-1R expression. C) Thirdly, in peripheral organs, selenium improves insulin sensitivity due to its antioxidant action. GLP-1: glucagon-like peptide 1; GLP-1R: GLP-1 receptor; GPx: glutathione peroxidase; IPF1: insulin promoter factor 1; IRS-1: insulin receptor substrate 1; P: phosphorylation; PKA: protein kinase A; ROS: reactive oxygen species; Se: selenium; Sepp1: selenoprotein P1.

redox state, caused by high selenoprotein expression, can compromise the protein folding of insulin and its receptor.

Pinto et al. (2011) demonstrated the action of various compounds containing selenium (sodium selenite, sodium selenate, selenomethionine, and methylseleninic acid) on insulin sensitivity in vitro in myocytes. The authors found that $>1 \mu \mathrm{M}$ doses of sodium selenite and methylseleninic acid were capable of inhibiting Akt phosphorylation, and attenuated the glucose uptake by decreasing the concentration of intracellular reactive oxygen species. This result can be attributed to the differences in bioavailability and metabolism of the selenium-containing compounds.

In addition, selenium may contribute to the induction of insulin resistance because of its role in the metabolism of carbohydrates and lipids (Steinbrenner, 2013). In a study on mice, Wang et al. (2014) found that high doses of selenium $(200 \mathrm{mg} / \mathrm{kg})$ can promote increased expression of carboxykinase phosphoenolpyruvate and glucose6-phosphatase, a key enzyme for gluconeogenesis. The authors also found that selenium promotes the accumulation and metabolism of fatty acids in the liver; this effect is related to the increased production of reactive oxygen species originating from mitochondrial oxidative phosphorylation, and hence the development of hepatic insulin resistance.

In this scenario, it is noteworthy that hyperglycemia favors hepatic Sepp 1 transcription by activating the forkhead box class $\mathrm{O} 1 \alpha(\mathrm{FoxO} 1 \alpha)$ and hepatocyte nuclear factor $4 \alpha$ (HNF- $4 \alpha$ ) transcription factors, through the action of peroxisomal proliferator-activated receptor gamma coactivator $1 \alpha$ (PCG-1 $\alpha)$. These transcription factors bind to a functional site in the Sepp1 promoter and upregulate gene expression. They are also involved in regulating the expression of hepatic glucose metabolism enzymes, and it is known that insulin promotes the inactivation of these enzymes. Therefore, under insulin resistance conditions, there may be an increase in Sepp1 concentrations concomitant with the increase in the activity of gluconeogenic enzymes. This situation may partially explain the associations between selenoprotein concentrations and the risk of type 2 diabetes mellitus (Jung et al., 2013; Mao, Teng, 2013; Steinbrenner et al., 2011; Steinbrenner, 2013).

A study by Jung et al. (2013) showed that induction of diabetes in rats by palmitate increases the expression of Sepp1 in HepG2 cells, thereby exacerbating insulin 
resistance. The activation of AMPK, induced by either salicylate or adiponectin, could reverse the increase in Sepp1 expression through phosphorylation of FoxO1 $\alpha$. Similar results were obtained by Takayama et al. (2014), wherein metformin inhibited the AMPK-mediated increased expression of Sepp1 in the H4IIEC3 hepatocytes of diabetic rats. On the other hand, coadministration of an AMPK antagonist reversed these results, indicating that this pathway can be a possible therapeutic target of insulin resistance and diabetes.

\section{CONCLUSION}

The action of selenium in the pathogenesis of insulin resistance is not fully elucidated, but our review has revealed that the main mechanisms involve the regulation of intracellular concentrations of reactive oxygen species, and carbohydrate and lipid metabolism. When ingested in sufficient amounts to maintain plasma concentrations in the range of 80-120 $\mu \mathrm{g} / \mathrm{L}$ (Rayman, 2012), selenium acts as an antioxidant and insulin-mimetic nutrient, favoring the synthesis and action of insulin. However, when selenium intake results in plasma levels above $120 \mu \mathrm{g} / \mathrm{L}$ (Rayman, 2012), the cellular redox state may become dysregulated, which can compromise the chemical interactions involved in the insulin signaling cascade. Nevertheless, it is noteworthy that the effects of selenium on insulin resistance are dependent on the chemical form (organic or inorganic), dose, and exposure time; these factors are not yet fully established. Further studies are needed to clarify the relation between selenium and insulin resistance in humans.

\section{REFERENCES}

Alizadeh M, Safaeiyan A, Ostadrahimi A, Estakhri R, Daneghian S, Ghaffari A, et al. Effect of L-arginine and selenium added to a hypocaloric diet enriched with legumes on cardiovascular disease risk factors in women with central obesity: a randomized, double-blind, placebo-controlled trial. Ann Nutr Metab. 2012;60(2):157-68.

Bahmani F, Kia M, Soleimani A, Asemi Z, Esmaillzadeh A. Effect of selenium supplementation on glycemic control and lipid profiles in patients with diabetic nephropathy. Biol Trace Elem. 2016;172(2):282-9.

Barakat GM, Moustafa ME, Bikhazi AB. Effects of selenium and exendin- 4 on glucagon-like peptide- 1 receptor, IRS-1, and Raf-1 in the liver of diabetic rats. Biochem Genet. 2012;50(1112):922-35.
Barakat GM, Moustafa ME, Khalifeh I, Hodroj MH, Bikhazi A, Rizk S. Effects of exendin-4 and selenium on the expression of GLP-1R, IRS-1, and preproinsulin in the pancreas of diabetic rats. J Physiol Biochem. 2016;73(3):387-94.

Bruce KD, Hanson MA. The developmental origins, mechanisms, and implications of metabolic syndrome. J Nutr. 2010;140(3):648-52.

Campbell SC, Aldibbiat A, Marriott CE, Landy C, Ali T, Ferris WF, et al. Selenium stimulates pancreatic beta-cell gene expression and enhances islet function. FEBS Lett. 2008;582(15):2333-7.

Chen H, Qiu Q, Zou C, Dou L, Liang J. Regulation of hepatic carbohydrate metabolism by selenium during diabetes. Chem Biol Interact. 2015;232:1-6.

Cominetti C, Bortoli MC, Abdalla DSP, Cozzolino SMF. Considerations about oxidative stress, selenium and nutrigenetics. Rev Nutr. 2011;36(3):131-53.

Cruz KJ, Oliveira AR, Pinto DP, Morais JB, Lima FS, Colli C, et al. Influence of magnesium on insulin resistance in obese women. Biol Trace Elem Res. 2014;160(3):305-10.

Czernichow S, Couthouis A, Bertrais S, Vergnaud AC, Dauchet L, Galan P, et al. Antioxidant supplementation does not affect fasting plasma glucose in the Supplementation with Antioxidant Vitamins and Minerals (SU.VI.MAX) study in France: association with dietary intake and plasma concentrations. Am J Clin Nutr. 2006;84(2):395-9.

D’Alessio D, Vahl T, Prigeon R. Effects of Glucagon-like Peptide 1 on the hepatic glucose metabolism. Horm Metab Res. 2004;36(11-12):837-41.

Faghihi T, Radfar M, Barmal M, Amini P, Qorbani M, Abdollahi $\mathrm{M}$, et al. A randomized, placebo-controlled trial of selenium supplementation in patients with type 2 diabetes: effects on glucose homeostasis, oxidative stress, and lipid profile. Am J Ther. 2014;21(6):491-495.

Farrokhian A, Bahmani F, Taghizadeh M, Mirhashemi SM, Aarabi MH, Raygan F, et al. Selenium supplementation affects insulin resistance and serum hs-CRP in patients with type 2 diabetes and coronary heart disease. Horm Metab Res. 2016;48(4):263-268. 
Feng W, Cui X, Liu B, Liu C, Xiao Y, Lu W, et al. Association of urinary metal profiles with altered glucose levels and diabetes risk: a population-based study in china. PLoS One. 2015;10(4):e0123742.

Gao H, Hägg S, Sjögren P, Lambert PC, Ingelsson E, Van Dam RM. Serum selenium in relation to measures of glucose metabolism and incidence of Type 2 diabetes in an older Swedish population. Diabetic Med. 2014;31(7):787-793.

García OP, Ronquillo D, Caamaño MC, Martínez G, Camacho $\mathrm{M}$, López V, et al. Zinc, iron and vitamins $\mathrm{A}, \mathrm{C}$ and $\mathrm{E}$ are associated with obesity, inflammation, lipid profile and insulin resistance in mexican school-aged children. Nutrients. 2013;5(12):5012-30.

Henriksen EJ, Diamond-Stanic MK, Marchionne EM. Oxidative stress and the etiology of insulin resistance and type 2 diabetes. Free Radic Biol Med. 2011;51(5):993-9.

Hirabara SM, Gorjão R, Vinolo MA, Rodrigues AC, Nachbar RT, Curi, R. Molecular targets related to inflammation and insulin resistance and potential interventions. J Biomed Biotechnol. 2012;2012:379024.

Iizuka Y, Ueda Y, Yagi Y, Sakurai E. Significant improvement of insulin resistance of GK rats by treatment with sodium selenate. Biol Trace Elem Res. 2010;138(1-3):265-71.

Jung TW, Choi HY, Lee SY, Hong HC, Yang SJ, Yoo HJ, et al. Salsalate and adiponectin improve palmitate-induced insulin resistance via inhibition of selenoprotein P through the AMPKFOXO1 $\alpha$ pathway. PLoS One. 2013;8(6):e66529.

Kim B, Feldman EL. Insulin resistance as a key link for the increased risk of cognitive impairment in the metabolic syndrome. Exp Mol Med. 2015;47(3):e149.

Kim HN, Song SW. Concentrations of chromium, selenium, and copper in the hair of viscerally obese adults are associated with insulin resistance. Biol Trace Elem Res. 2014;158(2):152-7.

Kwon H, Pessin JE. Adipokines mediate inflammation and insulin resistance. Front Endocrinol (Lausanne). 2013;4:71.

Labunskyy VM, Lee BC, Handy DE, Loscalzo J, Hatfield DL, Gladyshev VN. Both maximal expression of selenoproteins and selenoprotein deficiency can promote development of type 2 diabetes-like phenotype in mice. Antioxid Redox Signal. 2011;14(12):2327-36.
Lee YS, Jun HS. Anti-diabetic actions of glucagon-like peptide-1 on pancreatic beta-cells. Metabolism. 2014;63(1):9-19.

Lei XG, Vatamaniuk MZ. Two tales of antioxidant enzymes on $\beta$ cells and diabetes. Antioxid Redox Signal. 2011;14(3):489-503.

Litvinova LS, Kirienkova EV, Mazunin IO, Vasilenko MA, Fattakhov NS. Pathogenesis of insulin resistance in metabolic obesity. Biochemistry (Moscow). 2014;8(3):191-202.

Mao J, Teng W. The relationship between selenoprotein P and glucose metabolism in experimental studies. Nutrients. 2013;5(6):1937-1948.

Misu H, Takamura T, Takayama H, Hayashi H, MatsuzawaNagata N, Kurita S, et al. A liver-derived secretory protein, selenoprotein $\mathrm{P}$, causes insulin resistance. Cell Metab. 2010;12(5):483-95.

Muntoni S, Muntoni, S. Insulin resistance: pathophysiology and rationale for treatment. Ann Nutr Metab. 2011;58(1):25-36.

Mutakin, Meiliana A, Wijaya A, Kobayashi K, Yamazaki C, Kameo S, et al. Association between selenium nutritional status and metabolic risk factors in men with visceral obesity. J Trace Elem Med Biol. 2013;27(2):112-116.

Pinto A, Speckmann B, Heisler M, Sies H, Steinbrenner, H. Delaying of insulin signal transduction in skeletal muscle cells by selenium compounds. J Inorg Biochem. 2011;105(6):812-20.

Pounis G, Costanzo S, Persichillo M, Curtis A, Sieri S, Vinceti $\mathrm{M}$ et al. Mushroom and dietary selenium intakes in relation to fasting glucose levels in a free-living Italian adult population: The Moli-sani Project. Diabetes Metab. 2014;40(1):34-42.

Rains JL, Jain SK. Oxidative stress, insulin signaling, and diabetes. Free Radic Biol Med. 2011;50(5):567-75.

Rayman MP. Selenium and human health. Lancet. 2012;379(9822):1256-68.

Rayman MP, Stranges S. Epidemiology of selenium and type 2 diabetes: Can we make sense of it? Free Radic Biol Med. 2013;65:1557-64.

Slattery MJ, Bredella MA, Thakur H, Torriani M, Misra M. Insulin resistance and impaired mitochondrial function in obese adolescent girls. Metab Syndr Relat Disord. 2014;12(1):56-61. 
Steinbrenner H, Hotze AL, Speckmann B, Pinto A, Sies H, Schott $\mathrm{M}$, et al. Localization and regulation of pancreatic selenoprotein P. J Mol Endocrinol. 2013;50(1):31-42.

Steinbrenner H, Speckmann B, Pinto A, Sies H. High selenium intake and increased diabetes risk: experimental evidence for interplay between selenium and carbohydrate metabolism. J Clin Biochem Nutr. 2011;48(1):40-5.

Steinbrenner, H. Interference of selenium and selenoproteins with the insulin-regulated carbohydrate and lipid metabolism. Free Radic Biol Med. 2013;65:1538-47.

Stranges S, Marshall JR, Natarajan R, Donahue RP, Trevisan M, Combs GF, et al. Effects of long-term selenium supplementation on the incidence of type 2 diabetes: a randomized trial. Ann Intern Med. 2007;147(4):217-23.

Takayama H, Misu H, Iwama H, Chikamoto K, Saito Y, Murao $\mathrm{K}$, et al. Metformin suppresses expression of the selenoprotein $\mathrm{P}$ gene via an AMP-activated kinase (AMPK)/FoxO3a pathway in H4IIEC3 hepatocytes. J Biol Chem. 2014;289(1):335-45.

Tencerova M, Aouadi M, Vangala P, Nicoloro SM, Yawe JC, Cohen JL, et al. Activated Kupffer cells inhibit insulin sensitivity in obese mice. FASEB J. 2015;29(7):2959-69.

Wang X, Zhang W, Chen H, Liao N, Wang Z, Zhang X et al. High selenium impairs hepatic insulin sensitivity through opposite regulation of ROS. Toxicol Lett. 2014;224(1):16-23.
Wei Z, Yao M, Li Y, He X, Yang Z. Dietary selenium deficiency exacerbates lipopolysaccharide-induced inflammatory response in mouse mastitis models. Inflammation. 2014;37(6):1925-31.

Winnier DA, Fourcaudot M, Norton L, Abdul-Ghani MA, Hu SL, Farook VS, et al. Transcriptomic identification of ADH1B as a novel candidate gene for obesity and insulin resistance in human adipose tissue in Mexican Americans from the Veterans Administration Genetic Epidemiology Study (VAGES). PLoS One. 2015;10(4):e0119941.

Zeng MS, Li X, Liu Y, Zhao H, Zhou JC, Li K, et al. A highselenium diet induces insulin resistance in gestating rats and their offspring. Free Radic Biol Med. 2012;52(8):1335-42.

Zhou J, Huang K, Lei XG. Selenium and diabetes - evidence from animal studies. Free Radic Biol Med. 2013;65:1548-56.

Zhou J, Xu G, Bai Z, Li K, Yan J, Li F, et al. Selenite exacerbates hepatic insulin resistance in mouse model of type 2 diabetes through oxidative stress-mediated JNK pathway. Toxicol Appl Pharmacol. 2015;289(3):409-18.

Zou C, Qiu Q, Chen H, Dou L, Liang, J. Hepatoprotective effects of selenium during diabetes in rats. Hum Exp Toxicol. 2016;35(2):114-23.

Received for publication on $22^{\text {nd }}$ November 2016 Accepted for publication on $30^{\text {th }}$ August 2017 